\title{
Relationship between peri-oestrus progesterone levels and time of ovulation by echography in pigs and influence of the interval between ovulation and artificial insemination (AI) on litter size
}

\author{
Michel TERQui ${ }^{\mathrm{a} *}$, Philippe GuILlOUET ${ }^{\mathrm{b}}$, \\ Marie-Christine MAUREL ${ }^{\mathrm{c}}$, Françoise MARTINAT-BotTÉ $^{\mathrm{a}}$ \\ a Équipe Ovocytes et Développement, INRA, PRMD, URA CNRS 1291, 37380 Nouzilly, France \\ b INRA, SEIA, 86480 Rouillé, France \\ ${ }^{\mathrm{c}}$ Équipe Hormones et Gamétogenèse, INRA, PRMD, URA CNRS 1291, 37380 Nouzilly, France
}

(Received 21 October 1999; accepted 13 July 2000)

\begin{abstract}
Two methods for the determination of ovulation were compared to one ultrasonography performed 5 times a day. Time of ovulation by echography was $40 \pm 5.8 \mathrm{~h}$ (mean \pm SD) after the onset of oestrus. Preovulatory LH rise (two blood samples per day) began near the onset of oestrus but, in our conditions, this parameter could not be used to predict ovulation. The basal level of progesterone (two blood samples per day) was determined with a non-linear model, the timing when progesterone rose more than one $\mathrm{SD}\left(0.3 \mathrm{ng} \cdot \mathrm{mL}^{-1}\right)$ coincided with the timing of ovulation determined by echography $\left(R^{2}=0.98\right)$. This method was efficient and was used in a field trial to measure the consequences of the variability of the interval between $\mathrm{AI}$ and ovulation on litter size. The interval between AI and ovulation had an effect on litter size; litter size decreased by one piglet when this interval increased by $10 \mathrm{~h}$.
\end{abstract}

pig / progesterone / echography / ovulation / prolificacy

Résumé - Chez la truie, relation entre la progestéronémie et le moment d'ovulation déterminé par échographie et incidence sur la taille de la portée de l'intervalle entre l'ovulation et l'insémination artificielle (IA). Deux méthodes de détermination de l'ovulation sont comparées à celle fondée sur 5 échographies par jour. Le moment d'ovulation par échographie est de $40 \pm 5,8 \mathrm{~h}$ (moyenne \pm sd) après le début de l'œstrus. Les concentrations plasmatiques de LH (mesurées 2 fois par jour) augmentent dès le début de l'œstrus mais dans nos conditions, ce paramètre ne permet pas de prédire l'ovulation. Le moment où la progestérone augmente de $1 \mathrm{SD}\left(0,3 \mathrm{ng} \cdot \mathrm{mL}^{-1}\right)$ au-dessus du niveau de base coïncide avec le moment d'ovulation déterminé par échographie $\left(R^{2}=0,98\right)$. Cette méthode, avec 2 prélèvements par jour, est donc fiable et a été utilisée en élevages pour étudier les conséquences de

* Correspondence and reprints

E-mail: terqui @ tours.inra.fr 
la variabilité du moment d'ovulation sur la taille de la portée. L'intervalle entre l'IA et l'ovulation affecte la taille de la portée, elle diminue d'un porcelet lorsque l'intervalle augmente de $10 \mathrm{~h}$.

porcin / progestérone / échographie / ovulation / prolificité

\section{INTRODUCTION}

Overall fertility rate of pig herds is very high in France [16]. The introduction of hyperprolific lines has improved mean prolificacy [10]; however, the variability of litter size is still large [1]. Ovulation rate [2] and embryonic survival $[9,20]$ remain variable and are the main causes of litter size variability. Recent studies pointed out, again, the importance of the interval between AI and ovulation on litter size $[6,17,28]$. These results derive from experimental conditions in which the females are inseminated once. This is far from common practice, since most farmers inseminate females at least twice. No information is available, demonstrating whether the timing of ovulation is still an important parameter when females are inseminated several times.

Weitze et al. [33] and Soede et al. [26] used echography to determine the timing of ovulation. This method offers several advantages, but it requires trained staff, good conditions for the examination [13] and does not provide the time of ovulation for all animals [17, 34]. For endocrine parameters such as progesterone and LH levels only blood samples which are easy to collect in field trials, are needed. Helmond et al. [6] used progesterone plasma levels during the peri-oestrus phase to detect ovulation. However, Soede et al. [27] report some discrepancies between the progesterone method and echography that come, presumably, from the determination of basal levels and progesterone increase.

Thus, two experiments were conducted, the first one related some endocrine parameters such as $\mathrm{LH}$ and progesterone with echography data to determine the timing of ovulation in a practical setting. For the second one, the easiest and most efficient method was used to investigate, in field conditions, the variability of the time of ovulation and the influence on litter size of the variability of the interval between AI and ovulation.

\section{MATERIALS AND METHODS}

\subsection{Experiment A}

Twenty nine Large White (LW) pubertal gilts were selected after at least 2 oestrous cycles. They received an 18 day treatment with a daily dosage of $20 \mathrm{mg}$ of Regumate ${ }^{\circledR}$ (Hoechst-Roussel-Vet, Pantin, France), to synchronise oestrus. Day 0 was the day of the end of the treatment [11]. In these conditions, $95 \%$ of the gilts were usually seen in oestrus 4 to 7 days after.

Oestrus detection began 2 days before the expected onset of oestrus and was performed three times a day at 07.00, 12.00 and $17.00 \mathrm{~h}$ with a teaser boar. Oestrus was defined according to the sequence characterised by Signoret [24]. When a female pig demonstrated all behaviour characteristics including the "standing" reaction or the active pursuit of the male, the sign + was noted. When none of these reactions was noticed, the sign - was recorded. When a female presented all behaviour signs but refused mounting, the sign $\sim$ was noted. The beginning of oestrus was therefore estimated differently according to the sequence of -, + and $\sim$. These definitions are illustrated in Figure 1.

Ultrasound examinations were performed with a $5 \mathrm{MHz}$ sectorial probe (Combison 
310 A Kretz, Hagueneau, France). The gilt was kept in a crate and the probe was placed in the inguinal area. The images were recorded on a video tape. The echography was performed twice the first day of oestrus then five times a day $(09.00,12.00,16.00$, 20.00 , and $24.00 \mathrm{~h}$ ) until one day after the end of oestrus. The time when follicles (black spots on the screen) disappeared or were disappearing was defined as the time of ovulation.

Jugular blood samples were collected twice daily (08.00 and 16.00) in heparinised tubes, from the 4th day after the end of Regumate ${ }^{\circledR}$ treatment, until $24 \mathrm{~h}$ after the end of oestrus.

Plasma was separated by centrifugation, collected and stored at $-20{ }^{\circ} \mathrm{C}$.

\subsection{Experiment B}

This experiment was carried out in five breeding herds involving a total of
220 crossbred sows. The herds were managed in farrowing batches every three weeks. The size of a batch varied from 15 to 23 females and one to four batches per herd were investigated. A batch was generated by gathering females with different physiological stages: most of them $(n=172)$ were sows and were weaned after four weeks of lactation, few were open $(n=15)$ and some gilts $(n=33)$ were added and a part of them were treated with a progestagen, Regumate ${ }^{\circledR}$, to synchronise their oestrus.

The oestrus was checked and blood samples were collected as described in experiment A. A group of 22 (10\%) females came into oestrus too late ( 9 days to 60 days after weaning) and were not included in this study. The other, 198 females $(90 \%)$ came into oestrus within seven days after weaning of lactating sows. They were inseminated two to five times during the oestrus period, with 3 billions of spermatozoa each time. The females inseminated only twice were

In a situation :

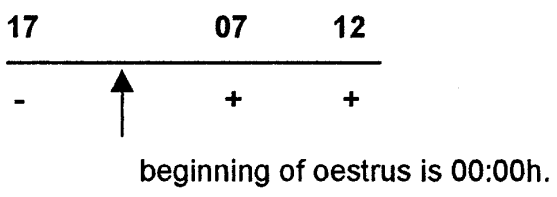

$00: 00$ is the mid time between $17: 00$ and $07: 00 \mathrm{~h}$.

and also when the sequence is :

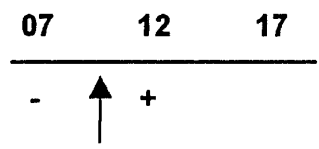

beginning of oestrus is 10:00h.

but when the sequence is :

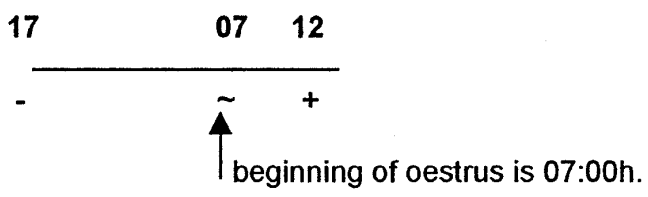

Figure 1. Three examples of oestrus notation. 
$135(68.2 \%)$, and 59 females (28.8\%) were inseminated 3 times; three were inseminated 4 times and one was inseminated 5 times. The first AI usually took place 8 to $24 \mathrm{~h}$ after the first positive detection of oestrus. The interval between the first AI and the second one ranged between 9 to $24 \mathrm{~h}$; this interval was variable within farms. Pregnancy was assessed by ultrasound scanning between 25 and 30 days as described elsewhere [13]. At farrowing, the total number of piglets was recorded. Fertility represented the percentage of inseminated females which farrowed.

\subsection{LH and progesterone determinations}

Plasma LH levels were measured by ELISA (REPROKIT, SANOFI, Libourne, France) according to Maurel [14]. This ELISA was carried out with two anti-LH polyclonal antibodies and a third antibody labelled with peroxydase. The limit of detection was $0.25 \mathrm{ng} \cdot \mathrm{mL}^{-1}$ with a calibration curve ranging from $0.25 \mathrm{ng} \cdot \mathrm{mL}^{-1}$ to $8 \mathrm{ng} \cdot \mathrm{mL}^{-1}$. A significant linear relationship $\left(R^{2}=0.98\right)$ was obtained between this method and the RIA method described previously [21]; the equation was $\mathrm{LH}_{\mathrm{RIA}}=(5 \pm$ $0.16) \times \mathrm{Lh}_{\text {ELISA }}$; there was no systematic bias, since the intercept was not significantly different from zero. The intra- and interassay coefficient of variations were 8.5 and $12.2 \%$ respectively for a plasma level of $2.7 \mathrm{ng} \cdot \mathrm{mL}^{-1}$. Several parameters were used to characterise $\mathrm{LH}$ rise. The beginning of the $\mathrm{LH}$ rise $(\mathrm{LHb})$ was when $\mathrm{LH}$ increased over one standard deviation, maximum of $\mathrm{LH}(\mathrm{LHm})$ was the highest recorded level and the end of the LH rise (Lhe) was when the level returned to pre-LH rise levels. The duration of the LH rise (LHd) was the difference between the end and the beginning.

Plasma progesterone levels were determined by radio-immuno-assay, as described previously [23]. The limit of detection was $0.05 \mathrm{ng} \cdot \mathrm{mL}^{-1}$ of plasma, the intra- and interassay coefficient of variations were 9 and
$14.5 \%$ respectively for a level of $2 \mathrm{ng} \cdot \mathrm{mL}^{-1}$. The basal progesterone level was determined from a non-linear model (see Sect. 2.4). The time of ovulation (Ovp) was defined as the time when progesterone increased from at least one SD above this basal level. The SD value was not fixed, but computed from the variance of the basal levels estimated by the non-linear model from the data of experiments A and B. The computed SD were of $0.3 \mathrm{ng} \cdot \mathrm{mL}^{-1}$ for both experiments and thus the same for all animals in the study.

\subsection{Definition of parameters and data analysis}

\subsubsection{Time of ovulation from progesterone levels}

Progesterone in plasma (Progesterone) during this peri-ovulatory phase first showed, a period with low and constant or basal levels (nbase) and then an exponential rise. A non-linear model was formulated according to these variations:

$$
\begin{aligned}
& \text { Progesterone }=\text { nbase if time } \leq \text { to taug } \\
& \text { nbase } \times \exp (\text { paug } \times(\text { time }- \text { taug }))
\end{aligned}
$$$$
\text { else }
$$

taug is the time when progesterone begins to rise, paug is related to the rate of progesterone increase and time is the interval from the beginning of oestrus in hours. This model was derived from a more general one describing progesterone variations during the oestrous cycle [35]; it was adjusted to data with the NLS2 software [7]. The model included heterogeneity of the variance of progesterone levels [7]. The plot of standardised residuals against the fitted values did not show any trend, or change in variability. This indicated that the model fit to the experimental data.

\subsubsection{Intervals between artificial insemination (AI) and ovulation}

As explained before, the females in experiment $\mathrm{B}$ were inseminated 2 to 5 times. 
In order to evaluate the effect of the interval between $\mathrm{AI}$ and ovulation on litter size, the different intervals, between inseminations and ovulation, were computed. A negative interval indicated that AI was performed before ovulation and a positive one that AI was performed after ovulation. The shortest of these intervals was determined and designated as the minimum interval between $\mathrm{AI}$ and ovulation. This parameter and its absolute value were used to assess the effect of the interval between AI and ovulation on fertility and litter size.

\subsubsection{Rank of the AI closest to ovulation}

The rank of the AI closest to ovulation, was also included in the analysis.

\subsubsection{Statistical analysis}

They were performed with S-PLUS [30] and SAS [22] software.

\section{RESULTS}

\subsection{Time of ovulation by echography (Experiment A)}

In three out of 29 gilts, it was not possible to determine the time of ovulation from the ultrasound scanning images. For the other females, ovulation occurred from 25 to $50 \mathrm{~h}$ after the onset of oestrus as illustrated in Figure 2. The average timing of ovulation after the beginning of oestrus was $40 \pm 5.8 \mathrm{~h}($ mean $\pm \mathrm{SD})$.

\subsection{Relationship between LH and ovulation (Experiment A)}

In our conditions, $\mathrm{LH}$ rose close to the onset of oestrus $(-2.6 \pm 9.6 \mathrm{~h}$; mean $\pm \mathrm{SD})$, reached a maximum of $11 \pm 4 \mathrm{ng} \cdot \mathrm{mL}^{-1}$ of plasma at $9 \pm 0.5 \mathrm{~h}$ after the beginning of oestrus. Then, its levels dropped to basal values $31 \pm 11 \mathrm{~h}$ after the beginning of oestrus.

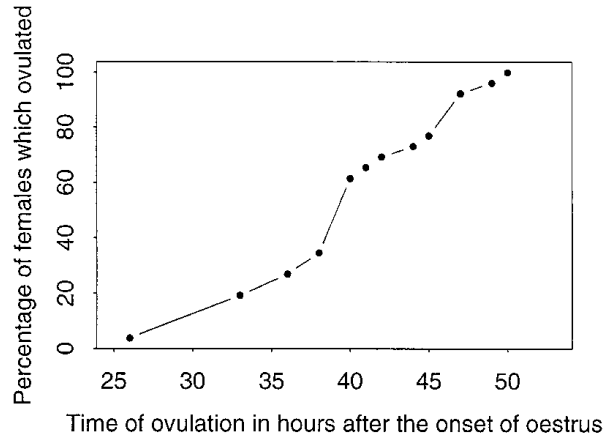

Figure 2. Distribution of the time of ovulation determined by echography as cumulated percent.
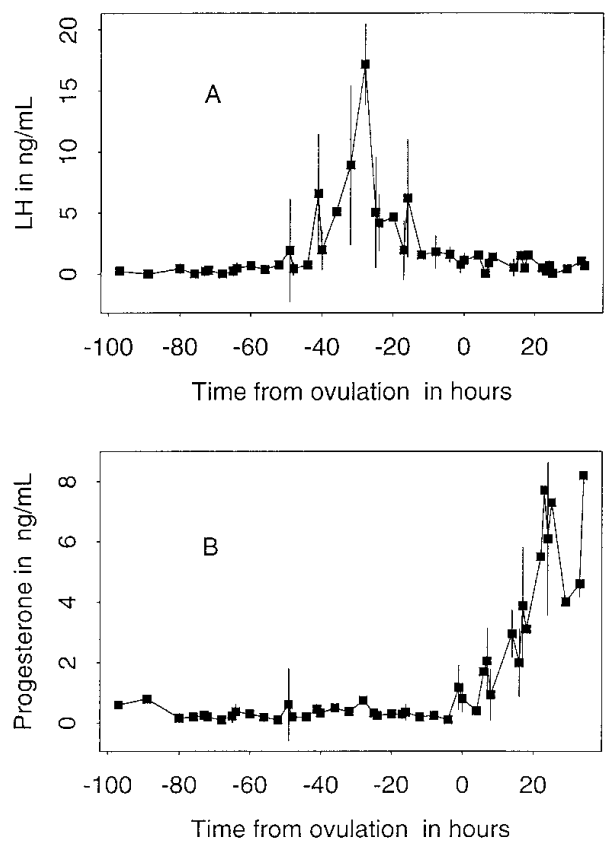

Figure 3. (A) Mean LH changes in peripheral plasma during the peri-ovulatory period in gilts (mean $\pm \mathrm{SD}$; experiment $\mathrm{A} ; n=26$ ). (B) Mean progesterone variations in peripheral plasma, during the peri-ovulatory period in gilts (mean \pm $\mathrm{SD}$; experiment A, $n=26$ ).

If time of ovulation was considered as time 0 (Fig. 3A), the LHb rise occurred $48 \mathrm{~h}$ before ovulation and mean $\mathrm{LH}$ levels reached a maximum of $17 \pm 3.3 \mathrm{ng} \cdot \mathrm{mL}^{-1}$ 
at $28 \mathrm{~h}$ before ovulation which was close to the mean time of the maximum LH levels $(31 \pm 9.6 \mathrm{~h}$ before ovulation). Then, the $\mathrm{LH}$ level decreased and LH was low when the female ovulated.

The interval between $\mathrm{LHb}$ rise and ovulation was quite variable and ranged from $24 \mathrm{~h}$ up to $65 \mathrm{~h}$; however in $70 \%$ of the females, LHb occurred within $24 \mathrm{~h}$. The mean value of LHb was $42 \pm 8.3 \mathrm{~h}$. There was a significant positive relationship between the interval from the onset of oestrus and $\mathrm{LHb}$ rise and the interval between the beginning of oestrus and ovulation $\left(R^{2}=0.39, p=0.0006\right)$. The time of $\mathrm{LH}$ rise $(\mathrm{LHm})$ and the duration of the $\mathrm{LH}$ rise (LHd) were not significantly related to the time of ovulation when the beginning of $\mathrm{LH}$ rise $(\mathrm{LHb})$ was taken into account.

The LH parameter that was related the most to the time of ovulation was the beginning of LH rise, which explained only $39 \%$ of the variability of the time of ovulation.

\subsection{Relationship between progesterone and ovulation (Experiment A)}

The mean pattern of progesterone was very different from that of LH (Fig. 3B). Progesterone levels were low and constant from -40 to $24 \mathrm{~h}$ after the beginning of oestrus. Around $40 \mathrm{~h}$ after the onset of oestrus, a time close to ovulation, progesterone rose sharply (Fig. 3B). Some fluctuations occurred; they corresponded to the variability in the timing of progesterone increase and to the sampling rhythm at particular times. The comparison of the progesterone pattern between sows, gilts with natural oestrus and gilts treated with Regumate ${ }^{\circledR}$ did not show any significant difference over time ( $p=0.82$, Experiment B). The calculated mean progesterone rise coincided with the occurrence of ovulation determined by ultrasound scanning. Moreover, the time interval between the results obtained from the progesterone profile and by echography (see Sect. 2.4) was $3 \pm 6 \mathrm{~h}$ (mean $\pm \mathrm{SD}$ ); it varied between -1 and $18 \mathrm{~h}$, but it was between -1 and zero for $65 \%$ of the cases (17 intervals out of 26). The linear relationship between the two methods was very strong since $R^{2}=0.981$ and the slope of the regression was $0.91(\mathrm{se}=0.025)$. This is illustrated in Figure 4.

\subsection{Relationship between oestrus and ovulation estimated by progesterone rise (Experiment B)}

The time of ovulation from the beginning of oestrus was estimated in farms using

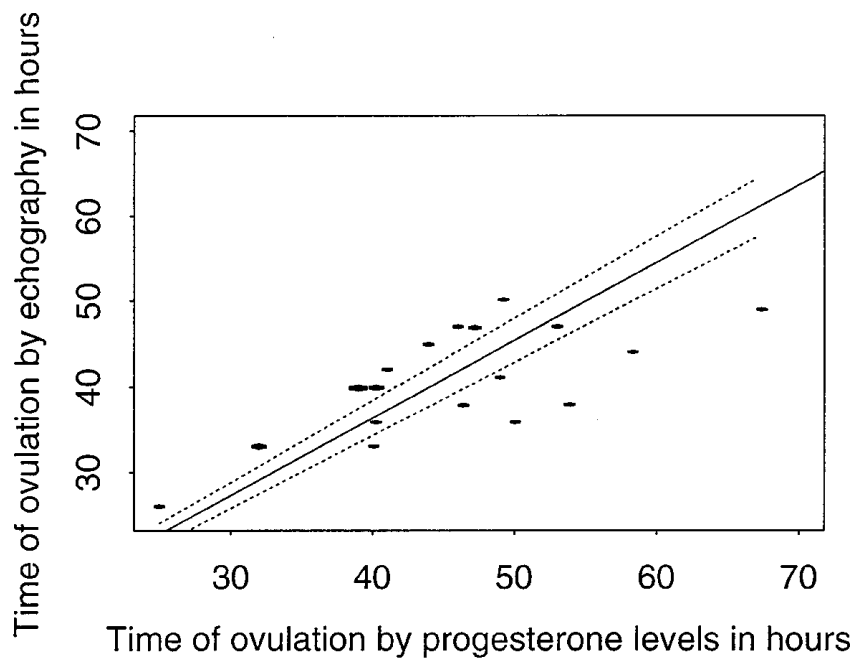

Figure 4. Relationship between the progesterone method and echography in determining the time of ovulation. - represents the regression line and the …..... 95\% confidence limits (experiment A; $n=26$ ). The size of the hexagon represents counts from 1 to 4 . 
the progesterone rise method; 198 out of 220 females were in heat during the experimental period. The variability of the timing of ovulation was considerable with a range between -2 and $88 \mathrm{~h}$ after the beginning of oestrus, with a mean value of $48 \pm$ $14 \mathrm{~h}$ (mean $\pm \mathrm{SD} ; n=198)$. Progesterone rise occurred in general during the last third of the oestrus period. The mean interval between the onset of oestrus and ovulation represented $71 \pm 5 \%$ of the oestrus duration, but the linear relationship between the duration of oestrus and the time of ovulation was not very close $\left(R^{2}=0.5\right)$. There was no significant difference between farms nor between parities in the mean time of progesterone rise and its variability. Furthermore, there was no difference in the time of progesterone rise between gilts, Regumate $^{\circledR}$ treated gilts and sows $(p=0.33)$.

\subsection{Variability of the interval between time of ovulation, estimated by progesterone levels and insemination (Experiment B)}

The females seen in oestrus $(n=198)$ were inseminated for the first time $20 \pm 7.8 \mathrm{~h}$ after the beginning of oestrus. The second AI occurred on the average, $18 \mathrm{~h}$ after the first. When females were inseminated three times, the last AI was $57 \pm 10.7 \mathrm{~h}$ after the onset of oestrus. The first and the second AI took place, in general, before ovulation; the mean intervals between AI and ovulation were respectively $-28 \pm 14.8$ and $-10 \pm 15.3 \mathrm{~h}$ for the first and second AI, respectively. If a third AI was performed, it was in general $8 \pm 16 \mathrm{~h}$ after ovulation. Despite the number of AI, the minimum interval between AI and ovulation was still large and varied in these farms between -46 to $+10 \mathrm{~h}$ with a mean of $-9 \pm 12 \mathrm{~h}(\mathrm{~m} \pm \mathrm{SD})$.

\subsection{Relationship between time of ovulation estimated by progesterone, insemination and fertility (Experiment B)}

The overall farrowing rate of the different farms was very high and ranged between
92.6 and $100 \%$ with an average of $95 \%$. There was no significant relationship between fertility and intervals between AI and ovulation. The rank of the AI closest to ovulation did not significantly affect female fertility. However, when the first AI was performed near ovulation, all the 15 females farrowed.

\subsection{Relationship between time of ovulation estimated by progesterone levels, insemination parity and litter size (Experiment B)}

Litter size (total number of piglets born) was high $(12.4 \pm 3.1$; mean \pm SD) but ranged from 4 to 20 piglets. As expected, parity had a significant effect on litter size $(p=0.0016)$. Litter size increased with parity and reached a maximum of $14 \pm$ 0.7 piglets (least square mean \pm se) with sows in the sixth parity, and then decreased.

In $73.7 \%$ of the cases, the second AI was the closest to the estimated ovulation time. The cases, when the first and the third AI were closest to ovulation, accounted for 7.7 and $18.6 \%$, respectively. The litter size was different according to the rank of the AI closest to ovulation $(p=0.04)$. Table I shows that the distributions were very different according to the rank of the AI closest to ovulation. When the females were subdivided into three groups according to litter size, there was only one female in the smallest litter class when the first AI was closest to ovulation; this female had 11 piglets. However, 35 to $40 \%$ of females were in this litter class when the second and the third AI were the closest. This difference of proportions according to rank of AI was significant $(p=0.03)$ but there was no significant difference in parity between these 3 classes.

The minimum interval between $\mathrm{AI}$ and ovulation affected litter size, as illustrated in Figure 5, where the minimum interval was split into seven classes. For 15 females ( $8.4 \%$ of females), the closest AI was performed between 6 and $10 \mathrm{~h}$ after ovulation; 
Table I. The effect of the rank of the AI closest to the estimated time of ovulation on litter size; $(n)=$ number of females.

\begin{tabular}{lccc}
\hline $\begin{array}{l}\text { Rank of the AI } \\
\text { closest to ovulation }\end{array}$ & $\begin{array}{c}\% \text { of litters } \\
<12 \text { piglets }\end{array}$ & $\begin{array}{c}\% \text { of litters } \\
\text { between } 12 \text { and } 16 \text { piglets }\end{array}$ & $\begin{array}{c}\% \text { of litters } \\
>16 \text { piglets }\end{array}$ \\
\hline 1st AI & $6.7(1)$ & $80(12)$ & $13.3(2)$ \\
2nd AI & $40.2(53)$ & $53(70)$ & $6.8(9)$ \\
3rd AI & $36.7(11)$ & $59.4(19)$ & $6.3(2)$ \\
\hline
\end{tabular}

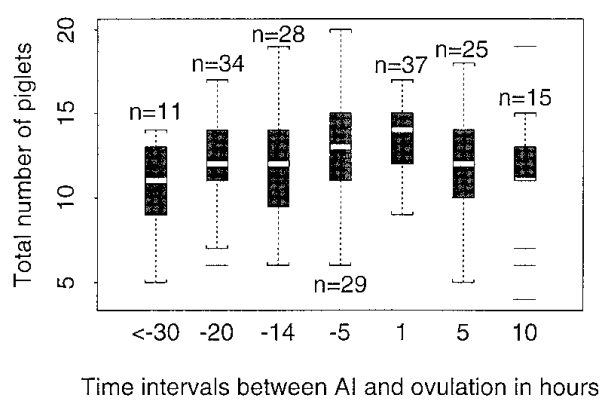

Figure 5. The effect of the minimum interval between $\mathrm{AI}$ and estimated ovulation on litter size $(n=179)$. The intervals between ovulation and AI were grouped into classes of time interval. The numbers close to each box are the number of females in each class.

in $34.6 \%$ of the females, the closest AI was performed near ovulation $(-4$ to $+5 \mathrm{~h})$. The litter size was maximal when females were inseminated just before ovulation.

Stepwise regressions between litter size and time of ovulation, times of AI, parity and absolute interval between $\mathrm{AI}$ and ovulation were calculated. The results indicate that the absolute value of the minimum interval between AI and ovulation and parity only has significant effects on the reduced model $(p=0.011)$.

To avoid an incidence of the rank of AI closest to ovulation, the quantitative effect of the minimum interval was determined in the situation where the second AI was the closest to ovulation; it involved $73.7 \%$ of the females. Furthermore, in a small number of females, first insemination was performed after ovulation; for these females, the effect of ageing of ovocytes was considered as being similar to that of spermatozoa and the absolute value of the minimum interval was used in the analysis; this was supported by the fact that the litter sizes of females inseminated $10 \mathrm{~h}$ before and $10 \mathrm{~h}$ after ovulation were not significantly different. The linear relationship between litter size and the absolute minimum interval between ovulation and AI is illustrated in Figure 6. The litter size decreased when the absolute minimum interval increased $(p=0.023)$. The effect was approximately one piglet for a $10 \mathrm{~h}$ interval between $\mathrm{AI}$ and ovulation.

\section{DISCUSSION}

There is a good fit between the timing of ovulation obtained from echography examination and those determined by the progesterone measurement. Thus progesterone measurements were applied in a field trial involving five farms. The results supported the hypothesis that, even when several inseminations are performed, the minimum interval of time between AI and ovulation still affects litter size. Furthermore, when the first AI was the closest to ovulation the percentage of small litter size ( $<12$ piglets) was low.

The time of ovulation for Large White gilts after oestrus synchronisation, was $40 \mathrm{~h}$ following the onset of oestrus determined by transcutaneous echography. This result 


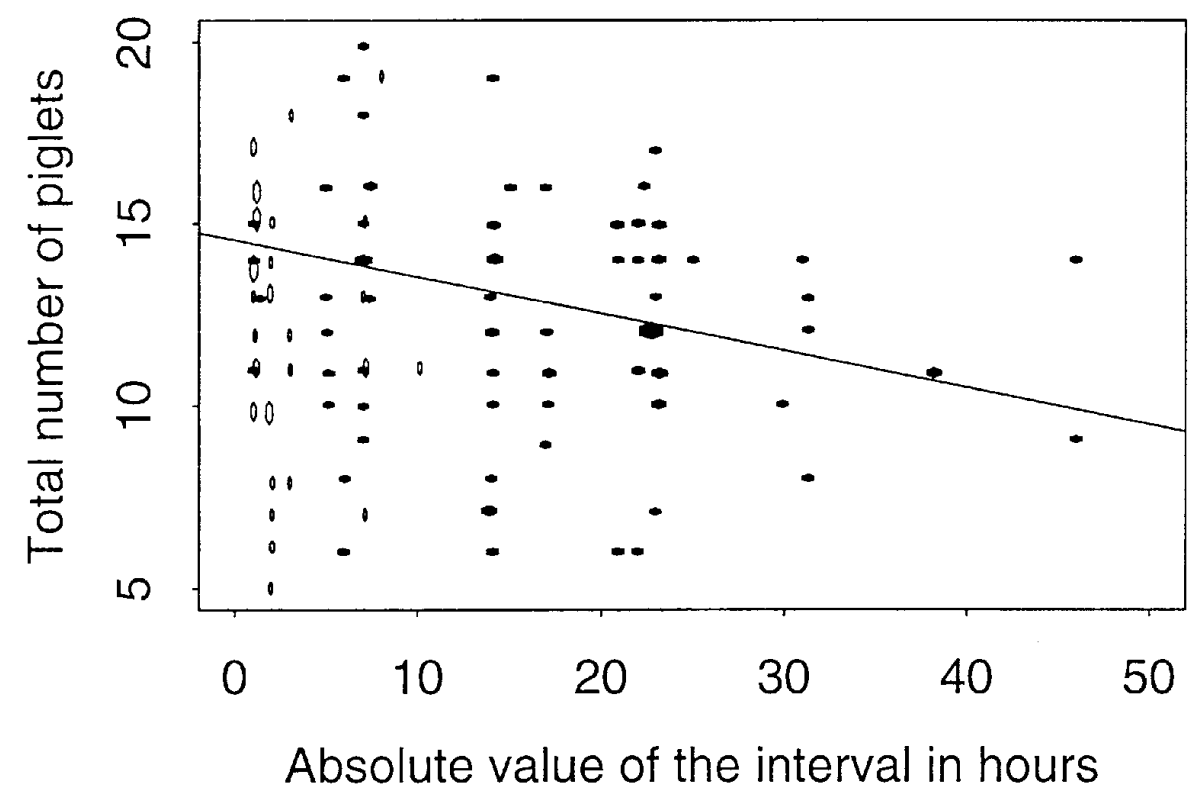

Figure 6. The effect of the absolute minimum interval between AI and ovulation on litter size when the second AI was the closest to ovulation. The regression line was estimated by a robust least square trimmed algorithm. $\left(R^{2}=0.20 ; n=132\right.$; slope $\left.=0.1 ; p<0.05\right)$; black hexagons are for AI before ovulation, open hexagons for AI after ovulation. The size of black hexagons represents the counts of data with values from 1 to 6 for the largest. The size of open hexagons represents counts of data with values from 1 to 4 .

was very close to the results of Weitze et al. [32] for unsynchronised females. With the same method in German Landrace gilts they found that ovulation occurs $44 \mathrm{~h}$ after the beginning of oestrus. The small difference can be explained by the genotypes, but also, by the difference in the frequency of oestrus detection and ultrasonography examination, which were performed twice daily in the study of Weitze et al. [33]. Our results were also very close to the values ( 38 to $42 \mathrm{~h}$ ) obtained in non-oestrus synchronised gilts by Signoret et al. [25] and Martinat-Botté et al. [12] for the same genotype but using laparascopy. Thus, there is no evidence of a difference in the time of ovulation between gilts with natural or synchronised oestrus. The success rate in determining the time of ovulation by transcutaneous echography was $89.6 \%$ (26 out 29 ) in our study, a level identical to the $88.4 \%$ (427 out 483 ) reported by Weitze et al. [34].

The pattern of LH was similar to that previously observed around the time of ovulation $[4,18,19,21]$. The timing of $\mathrm{LH}$ surge relative to the onset of oestrus and ovulation was the same as that obtained by others $[6,15,27]$. The correlation between the onset of LH rise and the timing of ovulation was not very high. This was presumably, mainly the consequences of the sampling regimen. However, the variability of the interval between LH peak and ovulation remains high even when blood samples are collected at $2 \mathrm{~h}$ intervals [15]. This suggests that other factors modulate the timing of ovulation. Weitze et al. [32] indicated that seminal plasma can influence the timing of ovulation. However, the results of Soede et al. [29] do not support this hypothesis. 
Progesterone changes recorded around oestrus were similar to those previously reported by Stabenfeldt et al. [31] and Soede et al. [27]. A non-linear model was fitted to the progesterone levels, which allowed an objective determination of individual basal level and the variability of this basal level among females (SD). The timing, when progesterone concentration rose more than one SD above the basal level, was very close to the time of ovulation. The regression, between these timings and those obtained by echography, was highly significant $\left(R^{2}=0.98\right)$ in gilts. The intercept was null; this indicated a lack of systematic bias. The determination of ovulation by progesterone slightly overestimated the time of ovulation compared to that obtained by echography; indeed the slope of the regression was 0.91 . This could have been the consequence of the difference between the frequency of echography examinations $\left(5 \mathrm{day}^{-1}\right)$ and blood sampling $\left(2\right.$ day $\left.^{-1}\right)$. These results differed from those of Helmond et al. [6], mainly because these authors used a fixed value of $1 \mathrm{ng} \cdot \mathrm{mL}^{-1}$ for progesterone rise. Such a large increase was observed between 6 and $14 \mathrm{~h}$ after ovulation in our study and in that of Soede et al. [27]. The definition of progesterone rise is critical. Indeed, Soede et al. [27], defined a timing for progesterone rise above $0.1 \mathrm{ng} \cdot \mathrm{mL}^{-1}$. The mean difference between this timing and ovulation by echography is only $3 \mathrm{~h} \mathrm{[27]} \mathrm{in} \mathrm{multiparous}$ sows. This observation supports our results in gilts, indicating a close relationship between ovulation and progesterone rise and the use of this progesterone increase to accurately determine a posteriori the time of ovulation. Blood samples were collected twice a day from the beginning of oestrus up to $24 \mathrm{~h}$ after the end of oestrus. The number of blood samples required, varied from 6 to 13 according to oestrus duration; however a mean of 9 samples were collected. With the progesterone method, the timing of ovulation was estimated for all females ( $n=198)$ of experiment B which were included in the study. The average ovula- tion interval ( $48 \mathrm{~h}$ ) from the beginning of oestrus, was close to that observed by Weitze et al. [34], by Soede et al. [27] and by Mburu et al. [15]. The differences were related to the differences in the way of computing the beginning of oestrus and timing of ovulation between the different studies. Ovulation occurred around the last third of oestrus; this was similar to that reported in several studies [15, 34]. However, this relationship was too variable $\left(R^{2}=0.5\right)$ to be used to determine the timing of ovulation. This agreed with the data of Soede et al. [28] and Nissen et al. [17] who obtained values of $R^{2}$ of 0.60 and 0.45 , respectively, for this relationship.

The adverse effect of long intervals between ovulation and $\mathrm{AI}$ on farrowing rate and litter size has been known for several decades $[3,5]$. The consequences of the interval between $\mathrm{AI}$ and ovulation were recently revisited with the determination of ovulation by echography [8]. Most of these studies only reported the effect on embryonic survival. The data of Nissen et al. [17] result from sows that were inseminated once. Observations with multiple AI have not been reported previously. We show that, even with several AI, the litter size was still dependant upon a minimum time interval between AI and ovulation. This parameter took into account that females were inseminated several times. Indeed, the litter size decreased by one piglet when this interval increased by ten hours. This amplitude was similar to that observed by Nissen et al. [17] with one AI. Furthermore, the variability of the litter size was low, when the first AI was close to ovulation; it increased, when the second or the third AI was close to ovulation. This effect was presumably not the consequence of a decrease in ovulation rate when the interval from the onset of oestrus and ovulation increased. Indeed, there was no significant relationship between this interval and litter size. This increase in variability could be the result of fertilisation of a part of oocytes by aged spermatozoa from the previous AI, these eggs would have a 
lower development potential [17]. In practical conditions, for the majority of the cases, the second insemination was the closest to ovulation; this contributed to the observed variability of litter size in pigs.

In practice, the variability of the minimum interval between artificial insemination and ovulation seemed to have a limited effect on fertility because females were inseminated several times, but an important effect on litter size. The best breeding strategy to reduce litter size variability is to have only one AI just before ovulation. However, this requires a predictable time of ovulation that is not normally achieved. The timing of ovulation is essential to improve the control of ovulation, and the progesterone method could be used to determine this timing, a posteriori.

\section{ACKNOWLEDGEMENTS}

The authors thank P. Després (INRA, PRMD) and his staff for their help with echography examination, Y. Forgerit (INRA, SEIA, 86480 Rouillé, France) for his skillful and efficient contribution in field trials, and D. André and C. Fagu (Atelier de Dosages Hormonaux, INRA, PRMD, 37380 Nouzilly, France). The authors also wish to thank members of the CETA (35 FDCETA, 35042 Rennes, France) who accepted blood sampling and observations in their piggery and COBIPORC (Le Val 35390, St-Gilles, France) for their financial contribution.

\section{REFERENCES}

[1] Dagorn J., Boulot S., Aumaitre A., Le Cozler Y., La prolificité des truies françaises en 1995-1996 : un spectaculaire bond en avant, INRA Prod. Anim. 11 (1998) 211-213.

[2] Driancourt M.A., Martinat-Botté F., Terqui M., Contrôle du taux d'ovulation chez la truie: l'apport des modèles hyperprolifiques, INRA Prod. Anim. 11 (1998) 221-226.

[3] Dzuik P., Estimation of optimum time for insemination of gilts and ewes by double-mating at certain times relative to ovulation, J. Reprod. Fertil. 22 (1970) 277-282.

[4] Foxcroft G.R., van de Wiel D.F.M., Endocrine control of the oestrous cycle, in: Cole D.J.A., Foxcroft G.R. (Eds.), Control of Pig Reproduction, Butterworths, London, 1982, pp. 161-177.
[5] Hancock J.L., Hovell G.J.R., Insemination before and after onset of heat in sows, Anim. Prod. 4 (1962) 91-96.

[6] Helmond F., Aarnink A., Oudenaarden C., Periovulatory hormone profiles in relation to embryonic development and mortality in pigs, in Sreenan J.M., Diskin M.G. (Eds), Embryonic Mortality in Farms Animals, Martinus Nijhoff, Dordrecht, 1986, pp. 119-125.

[7] Huet S., Bouvier A., Gruet M.A., Jolivet E., Statisticals tools for nonlinear regression, A practical guide with S-PLUS examples, Springer Series in Statistics, New York, 1996.

[8] Kemp B., Soede N.M., Consequences of variation in interval from insemination to ovulation on fertilization in pigs, J. Reprod. Fertil. Suppl. 52 (1997) 79-89.

[9] Lambert E., Willians D.H., Lynch P.B., Hanrahan T.J., McGeady T.A., Austin F.H., Boland M.P., Roche J.F., The extent and timing of prenatal loss in gilts, Theriogenology 36 (1991) 655-665.

[10] Legault C., Génétique et prolificité chez la truie : la voie hyperprolifique et la voie sinoeuropéenne, INRA Prod. Anim. 11 (1998) 214-218.

[11] Martinat-Botté F., Bariteau F., Badouard B., Terqui M., Control of pig reproduction in a breeding programme, J. Reprod. Fertil. Suppl. 33 (1985) 211-228.

[12] Martinat-Botté F., Bazer F.W., Thatcher W.W. Terqui M., Locatelli A., Chupin D., Oestrus, ovulation, conceptus and uterine development in Large White (LW) and hyperprolific Chinese Meishan (MS) gilts, Annual Conference of the Society for the Study of Fertility, York, July 1987, 44 (Abstract).

[13] Martinat-Botté F., Renaud G., Madec F., Costiou P., Terqui M., Échographie et reproduction chez la truie. Bases et applications pratiques, Coédition INRA Editions \& Hoechst Roussel Vet, Paris, 1998, $104 \mathrm{pp}$.

[14] Maurel M.C., Development of an ELISA kit for the determination of LH on farm, $7^{\mathrm{e}}$ Réunion A.E.T.E., Cambridge, 14-15 September 1991 , p. 176.

[15] Mburu J.N., Einarsson S., Dalin A.M., Rodriguez-Martinez H., Ovulation as determined by transrectal ultrasonography in multiparous sows: relationships with oestrous symptoms and hormonal profiles, J. Vet. Med. A 42 (1995) 285-292.

[16] Mercat M.J., Floch M., Pellois H., Runavot J.P., Conséquences d'une réduction du nombre de spermatozoïdes par dose d'insémination sur les performances de reproduction des truies, J. Rech. Porcine France 31 (1999) 53-58.

[17] Nissen A.K., Soede N.M., Hyttel P., Schmidt M., D'hoore L., The influence of time of insemination relative to time of ovulation on farrowing frequency and litter size in sows as investigated by ultrasonography, Theriogenology 47 (1997) 1571-1582. 
[18] Niswender G.D., Reichert L.E., Zimmerman D.R., Radioimmunoassay of serum levels of luteinizing hormone throughout the estrous cycle in pigs, Endocrinology 87 (1970) 576-580.

[19] Parvizi N., Elsaesser F., Smidt D., Ellendorff F., Plasma luteinizing hormone and progesterone in the adult female pig during the oestrous cycle, late pregnancy and lactation, and after ovariectomy and pentobarbitone treatment, J. Endocrinol. 69 (1976) 193-203.

[20] Pope W.P., First N.L., Factors affecting the survival of pig embryos, Theriogenology 23 (1985) 91-105.

[21] Prunier A., Martinat-Botté F., Ravault J.P. Camous S., Perioestrous patterns of circulating LH, FSH, Prolactin and Oestradiol-17ß in the gilt, Anim. Reprod. Sci. 14 (1987) 205-218.

[22] SAS Institute Inc., SAS/STAT® Guide for personal computers, Version 6.12, CARY NC, SAS Institute Inc., 1997.

[23] Saumande J., Tamboura D., Chupin D., Changes in milk and plasma concentration of progesterone in cows after treatment to induce superovulation and their relationship with number of ovulations and of embryos collected, Theriogenology 23 (1985) 719-736.

[24] Signoret J.P., Reproductive behaviour of pigs, J. Reprod. Fertil. Suppl. 11 (1970) 105-117.

[25] Signoret J.P., du Mesnil du Buisson F., Mauléon P., Effect of mating on the onset and duration of ovulation in the sow, J. Reprod. Fertil. 31 (1972) 327-330.

[26] Soede N.M., Noordhuizen J.P.T.M., Kemp B., The duration of ovulation in pigs, studied by transrectal ultrasonography, is not related to early embryonic diversity, Theriogenology 38 (1992) 653-666.

[27] Soede N.M., Helmond F.A., Kemp B., Periovulatory profiles of oestradiol, $\mathrm{LH}$ and progesterone in relation to oestrus and embryo mor- tality in multiparous sows using transrectal ultrasonography to detect ovulation, J. Reprod. Fertil. 101 (1994) 633-641.

[28] Soede N.M., Wetzels C.C.H., Zondag W. de Koning M.A.I., Kemp B., Effects of time of insemination relative to ovulation, as determined by ultrasonography, on fertilization rate and accessory sperm count in sows, J. Reprod. Fertil. 104 (1995) 99-106.

[29] Soede N.M., Bouwman E.G., Kemp B., Semina plasma does not advance ovulation in hCGtreated sows, Anim. Reprod. Sci. 54 (1998) 23-29.

[30] S-PLUS Guide to statistical and mathematical analysis, Version 4.0, Data Analysis Products Division of MathSoft, Inc., Seatle, 1997.

[31] Stabenfeldt G.H., Akins E.L., Ewing L.L., Morrissette M.C., Peripheral plasma progesterone levels in pigs during the oestrous cycle, J. Reprod. Fertil. 20 (1969) 443-449.

[32] Weitze K.P., Habeck O., Willmen T., Rath D. Detection of ovulation in the sow using transcutaneous sonography, Zuchthygiene 24 (1989) 40-42.

[33] Weitze K.F., Rath D., Willmen T., Waberski D., Lotz J., Advancement of ovulation in the sow related to seminal plasma application before insemination, Reprod. Domest. Anim. 25 (1990) 61-67.

[34] Weitze K.F., Wagner-Rietschel H., Waberski D., Richter L., Krieter J., The onset of heat after weaning, heat duration and ovulation as major factors in AI timing in sows, Reprod. Domest. Anim. 29 (1994) 433-443.

[35] Yenikoye A., Mariana J.C., Ley J.P., Jolivet E., Terqui M., Lemon-Resplandy M., Modèle mathématique de l'évolution de progestérone chez la vache : application et mise en évidence de différence entre races. Reprod. Nutr. Dev. 21 (1981) 561-575. 